\title{
Electrochemical Performance Measurements of PBI-Based High-Temperature PEMFCs
}

\author{
Javier Parrondo, Chitturi Venkateswara Rao, Sundara L. Ghatty, and B. Rambabu
}

Solid State Ionics and Surface Science Laboratory, Department of Physics, Southern University and A\&M College, Baton Rouge, LA 70813, USA

Correspondence should be addressed to B. Rambabu, rambabu@cox.net

Received 15 July 2010; Accepted 25 August 2010

Academic Editor: Benjamín R. Scharifker

Copyright ( 92011 Javier Parrondo et al. This is an open access article distributed under the Creative Commons Attribution License, which permits unrestricted use, distribution, and reproduction in any medium, provided the original work is properly cited.

Acid-doped poly $\left(2,2^{\prime}\right.$-m-phenylene-5, $5^{\prime}$-bibenzimidazole $)$ membranes have been prepared and used to assemble membrane electrode assemblies (MEAs) with various contents of PBI (1-30 wt.\%) in the gas diffusion electrode (GDE). The MEAs were tested in the temperature range of $140^{\circ} \mathrm{C}-200^{\circ} \mathrm{C}$ showing that the $\mathrm{PBI}$ content in the electrocatalyst layer influences strongly the electrochemical performance of the fuel cell. The MEAs were assembled using polyphosphoric acid doped PBI membranes having conductivities of $0.1 \mathrm{~S} \mathrm{~cm}^{-1}$ at $180^{\circ} \mathrm{C}$. The ionic resistance of the cathode decreased from 0.29 to $0.14 \mathrm{Ohm}_{-} \mathrm{cm}^{2}\left(180^{\circ} \mathrm{C}\right)$ when the content of PBI is varied from 1 to $10 \mathrm{wt} . \%$. Similarly, the mass transfer resistance or Warburg impedance increased 2.5 times, reaching values of $6 \mathrm{Ohm}-\mathrm{cm}^{2} .5 \mathrm{wt} . \%$ PBI-based MEA showed the best performance. The electrochemical impedance measurements were in good agreement with the fuel cell polarization curves obtained, and the optimum performance was obtained when overall resistance was minimal.

\section{Introduction}

Polymer electrolyte membrane fuel cell (PEMFCs) operated in the temperature range $160^{\circ} \mathrm{C}$ to $200^{\circ} \mathrm{C}$ offer benefits, over low temperature operation $\left(80^{\circ} \mathrm{C}\right)$, such as the elimination of humidification requirements, increased tolerance to fuel impurities, more available fuels, lower fuel reforming costs, and smaller radiators [1]. In recent years, polybenzimidazole (PBI)-phosphoric acid-based membranes have been successfully employed to meet requirements such as chemical and thermal stability for high-temperature operation [2-8]. However, some of the following problems have been delaying the progress of PBI membranes: poor mechanical properties due to the use of low molecular weight polymers, low ionic conductivities owing to low phosphoric acid loading [7, 9], degradation due to loss of phosphoric acid, and low $\mathrm{Pt}$ utilization due to the adsorption of phosphate ions onto the catalyst surface and oxidation of platinum $[10,11]$.

The two PBI polymer systems, which have been thoroughly investigated as acid-imbibed systems, are based on commercially available poly $\left(2,2^{\prime}\right.$-m-phenylene- $5,5^{\prime}$ bibenzimidazole) (m-PBI) and poly(2,5-benzimidazole)
(AB-PBI) [2, 12-16]. Recently, a sol-gel process allowing the synthesis of a variety of PBI chemical structures was reported and employed in the preparation of commercial membranes [17-19]. This method, called polyphosphoric acid process (PPA process), uses polyphosphoric acid (PPA) as the polycondensation agent, polymerization solvent, and membrane casting solvent. The phosphoric acid content of membranes produced by casting PPA solution of the polymer can be more than $95 \mathrm{wt} . \%$, or up to 70 phosphoric acid molecules per PBI repeat unit [13]. The properties that prompted the selection of these specific membranes, in comparison to the ones prepared by casting, and subsequent acid treatment, were its high phosphoric acid doping levels, good mechanical properties, excellent conductivities, and long-term stabilities.

In order for maximum power production, the manufacturing of membrane electrode assemblies operating in the temperature range of $120^{\circ} \mathrm{C}-200^{\circ} \mathrm{C}$ is highly dependent upon optimization of electrode structure. The data yielded from the performance of the ABPBI polymer-prepared MEAs electrodes was analyzed using polarization curves, and it was concluded that the optimum results are obtained 
with electrodes having 20 wt.\% of ABPBI [20]. For better understanding of the impact of the ionomer in the cathode catalysts layer on cell performance, the total potential losses were separated into activation, ohmic, and concentration losses. The penetration of the PBI-phosphoric acid ionomer into the pores results in low utilization of the platinum catalyst, and it is concluded that this activation loss is the main contributor to the total potential loss.

The activation loss in the fuel cell was lowest with $10 \mathrm{wt} . \%$ ionomer in the catalyst layer. MEAs prepared with high platinum content and a thin catalyst layer on both the anode and cathode perform the best $[10,20,21]$. It is important to identify the optimum content of PBI in the electrocatalysts ink/electrode composition of the MEAs for HT-PEMFCs. The studies dealing with electrode composition and processing of MEAs and their performance have been reported; however, there is a need for systematic studies to understand the transport processes within the electrodes for high-temperature (HT) operation and further optimization of the MEA structure and composition.

Various internal losses within the voltage response are difficult to differentiate in analysis of polarization curves. Impedance spectroscopy (EIS) was used for further quantifying and discriminating among the various losses encountered since EIS can separate individual transport processes depending on their characteristic time constants. These two techniques together allow a better understanding of the interfacial reactions at the membrane and electrodes.

This paper analyzes the effect of PBI concentration in the electrocatalysts ink/electrode composition on the ion transport and thereby the performance of the fuel cell. A parallel analysis of the polarization curves and impedance spectroscopy measurements are needed for the identification of the limiting steps in the overall process. This synthesis of data clarifies the effect of PBI concentration on the fuel cell performance. In addition, we attempt to quantify the effect of the composition of the electrode on the ionic conductivity and mass transport resistances within the electrode accounting oxygen mass transport through polymeric layer covering catalyst surface. Impedance modeling along with the polarization curve analysis of the high-temperature PBIbased MEAs are reported in this paper.

\section{Experimental Section}

2.1. Materials. Isophthalic acid (99\%) and platinum, nominally $40 \mathrm{wt} . \%$ on carbon black were purchased from Alfa Aesar. 3, 3'-Diaminobenzidine (99\%), N, N' Dimethylacetamide (99.5\%, DMAc), Lithium chloride (99+\%, ACS reagent) and polyphosphoric acid (115\%) were purchased from Sigma Aldrich.

\subsection{Synthesis of $m$-Polybenzimidazole and Fabrication of} PBI Membranes. m-polybenzimidazole (m-PBI) polymer was synthesized following the procedure described by Xiao et al. [17]. In a typical synthesis, $3.7135 \mathrm{~g}$ of isophthalic acid $(22.35 \mathrm{mmol})$ and $4.7896 \mathrm{~g}$ of $3,3^{\prime}$-diaminobenzidine $(22.35 \mathrm{mmol})$ were added to a three-neck reaction flask in an Argon-filled glovebox, followed by $91.5 \mathrm{~g}$ of polyphosphoric acid. The reaction mixture was stirred using a mechanical overhead stirrer, purged with a slow stream of nitrogen and maintained at $190^{\circ} \mathrm{C}-220^{\circ} \mathrm{C}$ for 16 to $24 \mathrm{~h}$. Inherent viscosity (IV) of the polymer was measured at a polymer concentration of $2 \mathrm{~kg} \mathrm{~m}^{-3}$ in concentrated sulfuric acid (96wt.\%) at room temperature using an Ubbelohde viscometer.

The membranes used in the fabrication of the MEAs were prepared by casting the PPA polymer solution onto glass plates using an adjustable film applicator (GARDCO MICROM II, Paul N. Gardner Company). The gate clearance was fixed in $0.015 \mathrm{~cm}$ to obtain after hydrolysis membranes of approximately $100 \mu \mathrm{m}$. Since polyphosphoric (PPA) acid is extremely hygroscopic, moisture is absorbed from the atmosphere, and PPA is hydrolyzed to phosphoric acid which produces a gel membrane [17]. The concentration of phosphoric acid was estimated by weighting a membrane sample before and after removing phosphoric acid by washing with ammonium hydroxide.

2.3. Membrane Electrode Assembly (MEA) Fabrication and High-Temperature PEMFC Testing. MEAs with an active area of $3.24 \mathrm{~cm}^{2}$ were assembled in a $5 \mathrm{~cm}^{2}$ single cell PEMFC with single serpentine flow fields (Fuel Cell Technologies, Inc.), using subgaskets to avoid direct pressure of the gaskets over the membrane and hence protecting the membrane from excessive pressure and stress during (Figure 1). The gas diffusion electrodes were placed at each side of the PBI membrane without hot pressing. The subgaskets had a thickness of $25 \mu \mathrm{m}$ and the gaskets $395 \mu \mathrm{m}$. The pinch, defined as the difference between the MEA and the gaskets thickness was $75 \mu \mathrm{m}$.

PBI was dissolved in $N, N^{\prime}$-dimethylacetamide with the aid of lithium chloride (5 wt.\%. PBI solution with $1.5 \%$ of $\mathrm{LiCl})$ by heat-treating the contents at $250^{\circ} \mathrm{C}(6.3 \mathrm{bar})$ for $6 \mathrm{~h}$ in a stainless steel reactor. The homogeneous solution obtained was subsequently used to prepare catalyst ink [12]. GDE were prepared by airbrush painting over the microporous area of a gas diffusion layer (GDL Sigracet GDL 10BB, $420 \mu \mathrm{m}$, SGL Carbon Group). Catalyst ink consisted of carbon supported catalyst (0.2 g, 40 wt.\% Pt/C, Alfa Aesar) to which DMAc ( $7.5 \mathrm{~g}$ ) and PBI solution ( $5 \mathrm{wt} . \%$ in DMAc) in the required amounts were added to attain concentrations of PBI of 1, 5, 10, 20, or $30 \mathrm{wt} . \%$ (dry basis). The ink slurry was stirred overnight to break up the catalyst powder in order to get a homogenous ink. The loading of each electrode was kept in $0.40 \pm 0.05 \mathrm{mg} \mathrm{Pt} \mathrm{cm}^{-2}$. Identical electrodes were used for the anode and cathode.

The performance of the MEAs was evaluated after conditioning for $24 \mathrm{~h}$ at $200 \mathrm{~mA} \mathrm{~cm}^{-2}$ by using a Compact Fuel Cell Test System model 850e (Scribner Associates, Inc.) controlled using FuelCell 3.9c software (Figure 1). The polarization curves were recorded at atmospheric pressure using dry oxygen and hydrogen at temperatures ranging from $160^{\circ} \mathrm{C}$ to $200^{\circ} \mathrm{C}$. Stoichiometric flows (1.2 stoichiometric ratio for hydrogen and 2 for oxygen) with minimum flow of $0.2 \mathrm{~L} \mathrm{~min}^{-1}$ were employed in the experiments. 


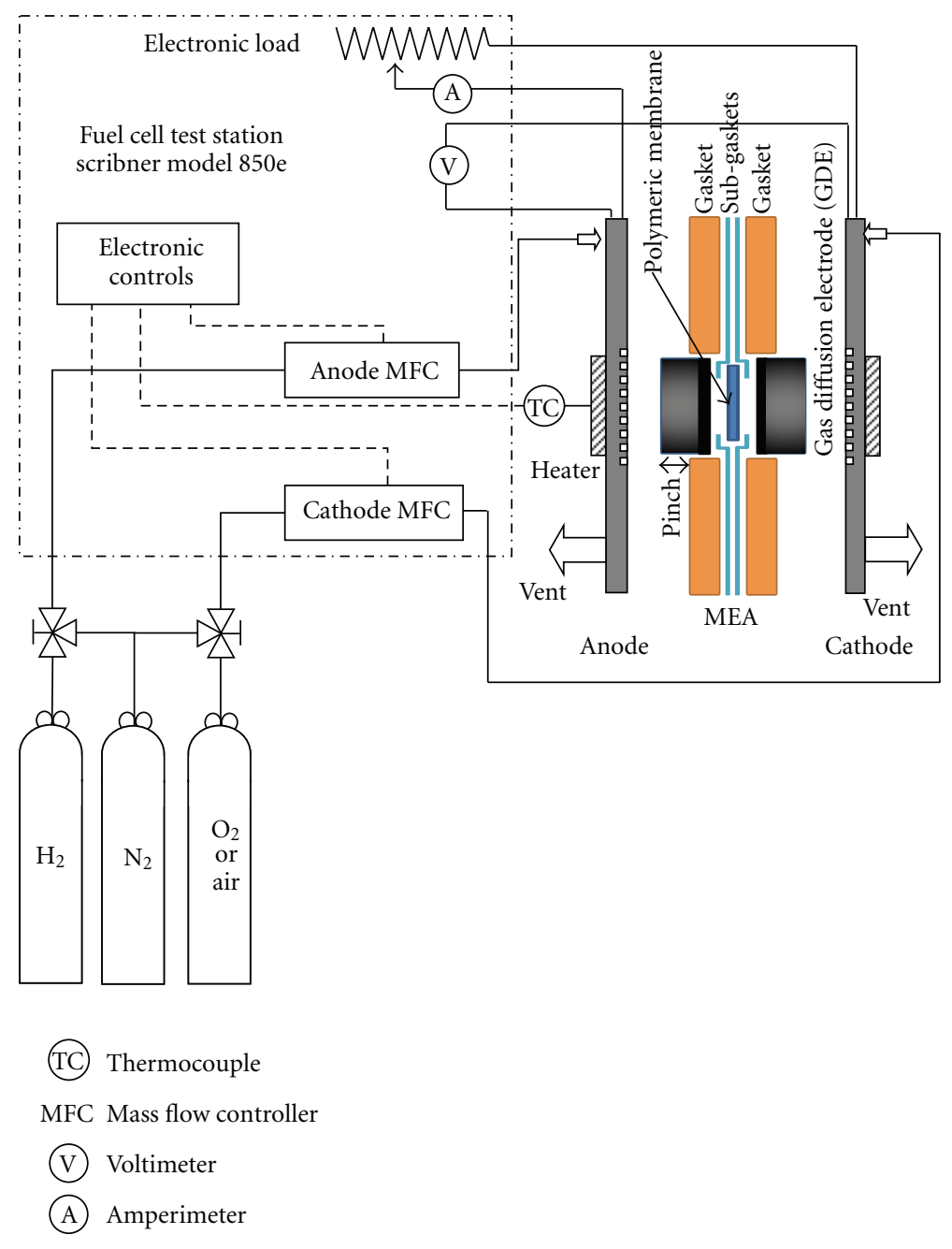

FIGURE 1: Schematic drawing of the fuel cell system employed in the experiments.

Cell resistance was measured by using current-interrupt technique.

Cyclic voltammetry (CV) and linear sweep voltammetry (LSV) were used to check the amount of active catalyst, the crossover of reactants and the absence of short circuits. The tests were performed using $0.2 \mathrm{~L} \mathrm{~min}^{-1}$ of dry hydrogen at the anode side (reference and counter-electrode) and $0.2 \mathrm{~L} \mathrm{~min}^{-1}$ of dry nitrogen at the cathode side (working electrode). $\mathrm{CV}$ was recorded in the potential range of 0.05 to $0.8 \mathrm{~V}$ at a scan rate of $40 \mathrm{mV} \mathrm{s}^{-1}$, and LSV in the potential range of 0.15 to $0.5 \mathrm{~V}$ at a scan rate of $2 \mathrm{mV} \mathrm{s}^{-1}$. The coulombic charge for hydrogen desorption $\left(\mathrm{Q}_{\mathrm{H}}\right)$ was used to calculate the ECA of the electrodes [22]. Only the cells demonstrating low hydrogen crossover (below $1 \mathrm{~mA} \mathrm{~cm}^{-2}$ ), as well as no shorting were chosen for further testing.

2.4. Impedance Spectroscopy. AC impedance spectra were recorded in $\mathrm{H}_{2} / \mathrm{N}_{2}$ (using Princeton Applied Research Potentiostat/Galvanostat model 273A and Frequency Response Detector 1025) and in $\mathrm{H}_{2} / \mathrm{O}_{2}$ mode (using the build-in FRA of Fuel Cell Test System model 850e) with a constant reactant flow rate of $0.2 \mathrm{~L} \mathrm{~min}^{-1}$. The cathode and anode are the working and counter electrode, respectively. In $\mathrm{H}_{2} / \mathrm{N}_{2}$ mode, an AC signal of $15 \mathrm{mV}$ amplitude, superimposed to a DC signal of $0.3 \mathrm{~V}$, was applied in the frequency range $50 \mathrm{kHz}$ to $1 \mathrm{~Hz}$ (potentiostatic mode) [23, 24]. Similarly in $\mathrm{H}_{2} / \mathrm{O}_{2}$ mode, a galvanostatic AC signal of $10 \%$ DC was applied in the frequency range $5 \mathrm{kHz}$ to $0.1 \mathrm{~Hz}$. The data obtained was fitted to different models using ZVIEW software (Version 3.1, Scribner Associates, Inc.). Since the oxidation of hydrogen is very fast compared with the reduction of oxygen, anode resistance can be neglected when calculating cathode resistance

\section{Results and Discussion}

3.1. Characterization of PBI Polymer. PBI, synthesized using polyphosphoric acid process, was characterized by means of inherent viscosity (IV) and phosphoric acid content. In agreement with the reported data, the acid content of the PBI membrane that was prepared in house, is $85 \mathrm{wt} . \%$. This weight is in correspondence to $18 \mathrm{~mol}$ of phosphoric acid per mol of polymer repeating unit, which yields the conductivities of $0.1 \mathrm{~S} \mathrm{~cm}^{-1}$ at $160^{\circ} \mathrm{C}[25,26]$. Inherent 
viscosity, which is an indirect measure of the molecular weight, was in the interval of $0.7-0.9 \mathrm{dL} \mathrm{g}^{-1}$, depending on the batch, being in agreement with published data $[2,17$, 27, 28]. Molecular weight was estimated using the MarkHouwink expression [29]

$$
\mathrm{IV}=1.35326 \times 10^{-4} \times M_{W}^{0.7328}
$$

The molecular weight calculated for the polymer prepared in house was in the range 115,000-150,000 $\mathrm{g} \mathrm{mol}^{-1}$.

3.2. Electrochemical Active Areas and Crossover Currents. As can be seen in Table 1, ECA were around $10 \mathrm{~m}^{2} \mathrm{~g}^{-1} \mathrm{Pt}$ at $180^{\circ} \mathrm{C}$. The reasons for the low platinum utilization, when compared with Nafion-based MEAs $\left(30-40 \mathrm{~m}^{2} \mathrm{~g}^{-1} \mathrm{Pt}\right.$ ), are due to the adsorption of phosphate ions onto catalyst surface, as well as excessive penetration of PBI and phosphoric acid into the catalytic pores [10].

It is shown in Table 1 that hydrogen crossover currents are below $1 \mathrm{~mA} \mathrm{~cm}^{-2}$ and open circuit voltages (OCV) around $0.9 \mathrm{~V}$. The linear sweep voltammetry does not reveal the presence of any short circuit in the MEAs.

3.3. Performance of PBI-Based MEAs. The effect of the amount of PBI in the electrode on polarization curves at $160^{\circ} \mathrm{C}, 180^{\circ} \mathrm{C}$, and $200^{\circ} \mathrm{C}$ are shown in Figure 2 . When the concentrations of PBI are in the interval 20-30 wt.\%, such as that used in the preparation of Nafion-based MEAs, and the cell voltages are below $0.4 \mathrm{~V}$, the performance was poor, with current densities below $100 \mathrm{~mA} \mathrm{~cm}^{-2}$. This performance result may come as a consequence of high-mass transfer resistances through the polymeric film surrounding catalyst particles. At $160^{\circ} \mathrm{C}$, the performance of 1, 5, and $10 \mathrm{wt} . \% \mathrm{PBI}$ electrodes were similar, but when the temperature was raised to $180^{\circ} \mathrm{C}$ and $200^{\circ} \mathrm{C}$, they differed, and the best results are obtained in electrodes having $5 \mathrm{wt}$ \% PBI.

The effect of temperature on the performance of MEAs prepared using $5 \mathrm{wt}$.\% PBI electrodes is shown in Figure 3. Best results were obtained when the MEA was operated at $180^{\circ} \mathrm{C}$ although the differences between 160 and $180^{\circ} \mathrm{C}$ were minimal. When temperature is raised from 180 to $200^{\circ} \mathrm{C}$, the voltage at $200 \mathrm{~mA} \mathrm{~cm}^{-2}$ decreases from 0.58 to $0.56 \mathrm{~V}$. These results are in agreement with PBI membranes with high platinum loadings $[27,28]$. This improvement could be due to better properties of PBI membranes prepared using PPA process that have higher ionic conductivities than membranes prepared by solution casting and acid treatment [13].

Better performances can be obtained by increasing $\mathrm{Pt}$ loadings in the anode and cathode since with more Pt, masstransfer resistances within the electrodes decrease because of less diffusion distances. The PBI-based MEAs prepared in this work have half of the $\mathrm{Pt}$ content compared to commercial membranes $\left(0.7-1.0 \mathrm{mg} \mathrm{Pt} \mathrm{cm}^{-2}\right)$ characterized in our laboratory [17].

Membrane resistance of our MEAs were in the range 0.1$0.2 \mathrm{Ohm}-\mathrm{cm}^{2}$ (Figures 2 and 3 ) depending on the experimental conditions. The ionic conductivity was estimated to be $60-100 \mathrm{mS} \mathrm{cm}^{-1}$ for membrane thickness of $100 \mu \mathrm{m}$. The
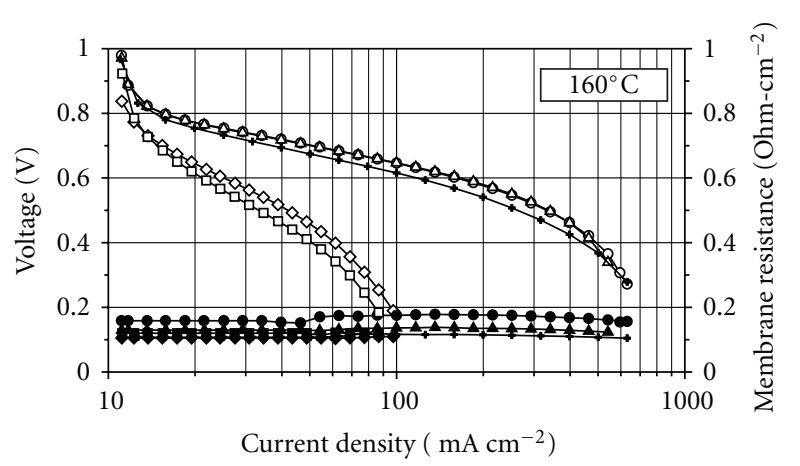

(a)

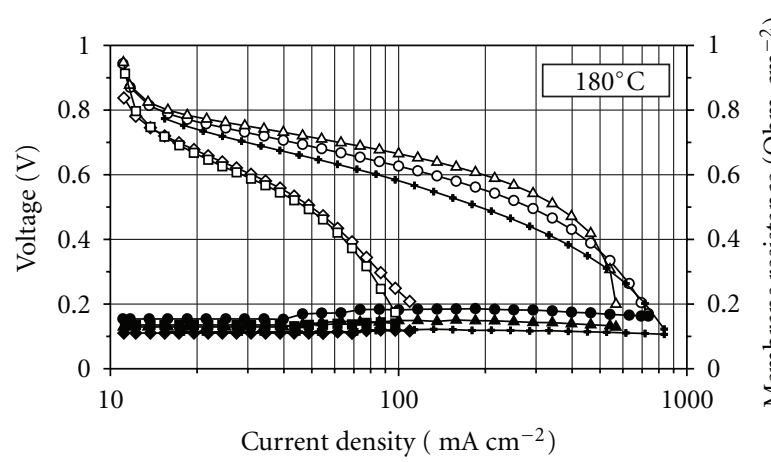

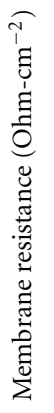

(b)

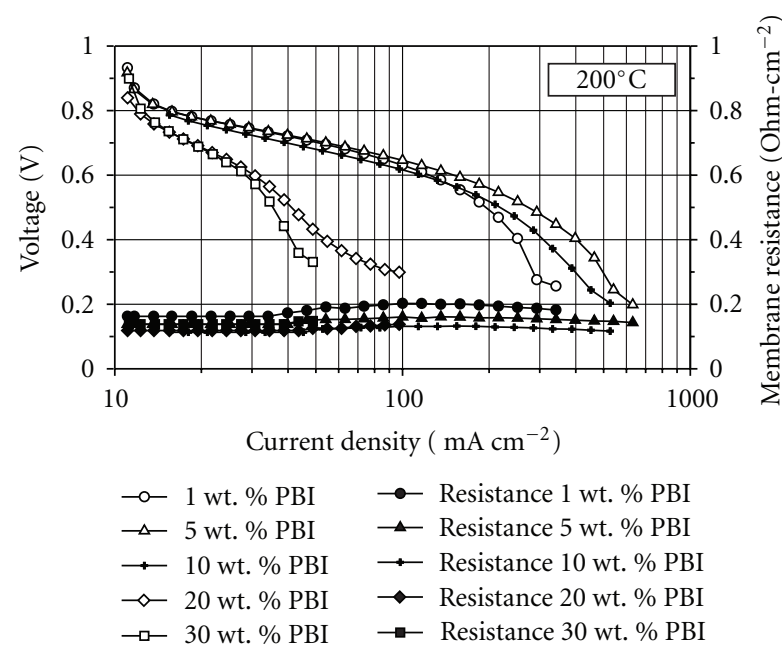

(c)

FIgURE 2: Polarization curves of PBI-based MEAs at 160, 180 and $200^{\circ} \mathrm{C}$ using dry gases at atmospheric pressure. $\mathrm{H}_{2}$ stoichiometric ratio: $1.2 ; \mathrm{O}_{2}$ stoichiometric ratio: 2 ; minimum flow: $0.2 \mathrm{~L} \mathrm{~min}^{-1}$; Pt loading (anode and cathode): $0.4 \mathrm{mg} \mathrm{cm}^{-2}$.

conductivities of the MEAs operated in the interval $140^{\circ} \mathrm{C}-$ $200^{\circ} \mathrm{C}$ using dry gases are increased and almost similar to the conductivities encountered in fully hydrated Nafion membranes at $80^{\circ} \mathrm{C}[30]$.

3.4. Ionic Resistance of the Cathode. Impedance spectroscopy data (obtained in $\mathrm{H}_{2} / \mathrm{N}_{2}$ mode) was fitted to a transmission line to model the distributed processes within the electrode 
TABLE 1: Electrochemical active areas (ECA) and crossover currents of PBI-based MEAs at $180^{\circ} \mathrm{C}$.

\begin{tabular}{lcccc}
\hline PBI content (wt.\%) & OCV $(\mathrm{V})$ & ECA $\left(\mathrm{m}^{2} \mathrm{~g}^{-1} \mathrm{Pt}\right)$ & Crossover current $\left(\mathrm{mA} \mathrm{cm}^{-2}\right)$ & Presence of short circuit \\
\hline 1 & 0.94 & 9.9 & 0.3 & No \\
5 & 0.95 & 9.8 & 0.7 & No \\
10 & 0.93 & 11.8 & 0.5 & No \\
20 & 0.85 & 11.0 & 0.9 & No \\
30 & 0.91 & 9.4 & 0.4 & No \\
\hline
\end{tabular}

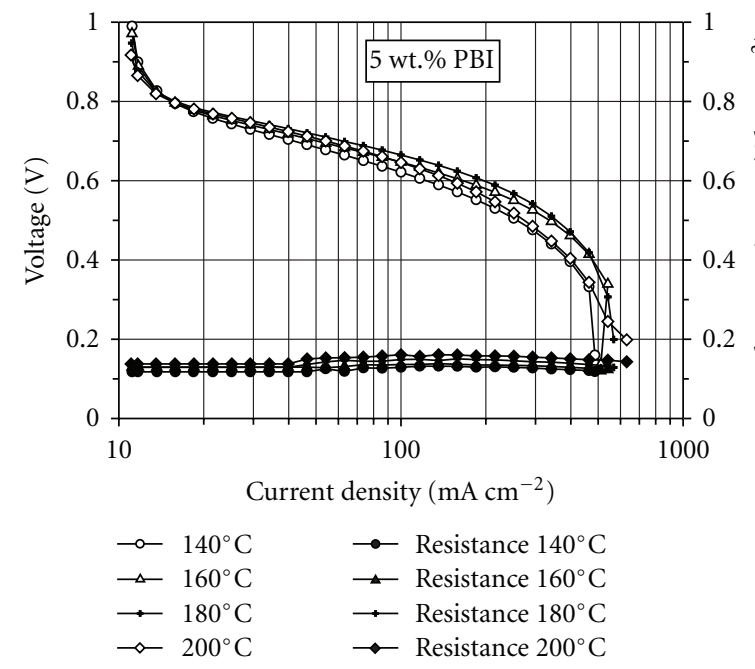

Figure 3: Polarization curves for 5 wt.\% PBI MEAs at atmospheric pressure and using dry gases. $\mathrm{H}_{2}$ stoichiometric ratio: $1.2 ; \mathrm{O}_{2}$ stoichiometric ratio: 2; minimum flow: $0.2 \mathrm{~L} \mathrm{~min}^{-1}$; Pt loading (anode and cathode): $0.4 \mathrm{mg} \mathrm{cm}^{-2}$.

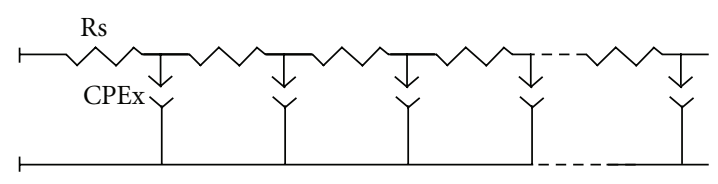

(a)

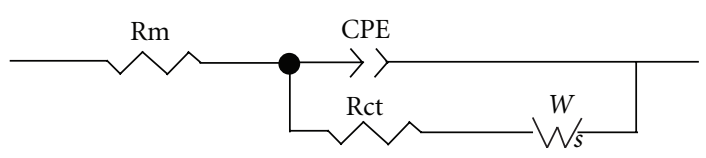

(b)

FIGURE 4: Equivalent circuits used (a) to model the impedance in a $\mathrm{H}_{2} / \mathrm{N}_{2}$ cell and (b) to model Warburg impedances.

(Figure 4(a)). The presence of ionic resistance in the electrode was observed by the presence of $45^{\circ}$ branch in the Nyquist plot at high frequencies (just before the intercept with the $x$-axis) which can be seen in Figure 5.

The increase of PBI content decreases ionic resistance of the cathode as illustrated in Table 2. In the case of electrodes with $1 \mathrm{wt} . \%$ of $\mathrm{PBI}$, the cathode resistance at $180^{\circ} \mathrm{C}$ was $0.29 \mathrm{Ohm}-\mathrm{cm}^{2}$. When the concentration is raised to 5 and $10 \mathrm{wt} . \%$, the resistance decreases to $0.14 \mathrm{Ohm}^{-}$ $\mathrm{cm}^{2}$, and further increase in the PBI content has no effect

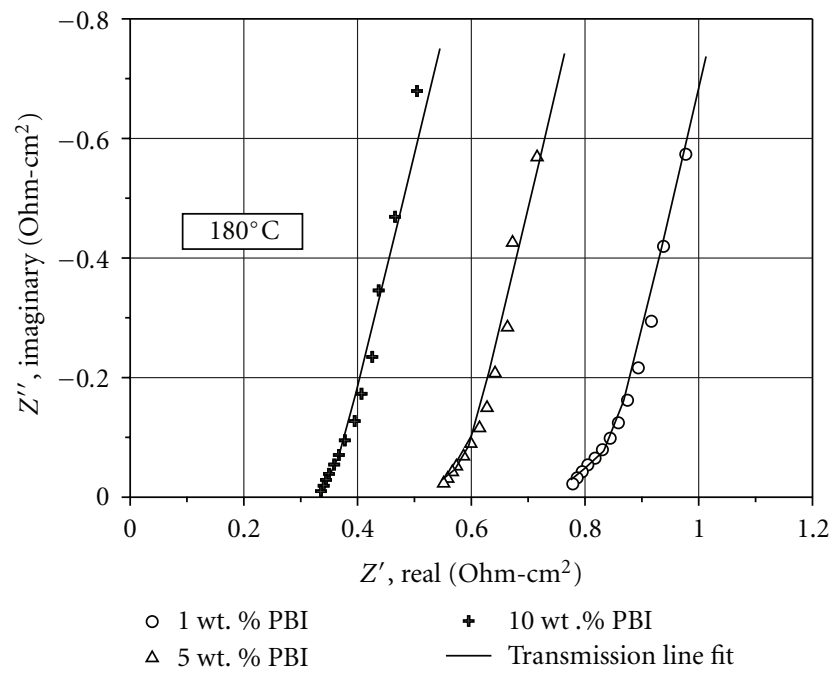

FIgURE 5: Nyquist plot showing the effect of PBI content on ionic resistance of MEAs at $180^{\circ} \mathrm{C}$. Pressure: 1 atm; $\mathrm{H}_{2}: 0.2 \mathrm{~L} \mathrm{~min}^{-1}$; $\mathrm{N}_{2}$ : $0.2 \mathrm{~L} \mathrm{~min}^{-1}$; Pt loading (anode and cathode): $0.4 \mathrm{mg} \mathrm{cm}^{-2}$. Impedance shifted along real axis to show separately the curves.

TABLE 2: Membrane and cathode resistances in PBI-based MEAs at $180^{\circ} \mathrm{C}$.

\begin{tabular}{lcc}
\hline PBI content (wt.\%) & $\begin{array}{c}\text { Membrane } \\
\text { resistance } \\
\left(\mathrm{Ohm}_{-} \mathrm{cm}^{2}\right)\end{array}$ & $\begin{array}{c}\text { Cathode } \\
\text { resistance } \\
\left(\mathrm{Ohm}_{-12}\right)\end{array}$ \\
\hline 1 & 0.18 & 0.29 \\
5 & 0.15 & 0.21 \\
10 & 0.12 & 0.14 \\
\hline
\end{tabular}

in the ionic resistance. This resistance is comparable with electrode ionic resistance in Nafion-based MEAs at $80^{\circ} \mathrm{C}$ under humidified conditions. The low ionic resistances in 5 and $10 \mathrm{wt} . \%$ electrodes can also be observed in Figure 5 by the small $45^{\circ}$ branch in the Nyquist plot.

The operating temperature of fuel cells also have an effect on the ionic conductivity of the electrode. Albeit, the membrane resistance is almost constant at all temperatures with the increased electrode resistance given in Table 3. A 4.5 -fold increase in the cathode resistance was observed when the temperature was raised from $140^{\circ} \mathrm{C}$ to $200^{\circ} \mathrm{C}$. The reasons for the decrease of ionic conductivity with temperature could be the low acid content in the electrodes, the loss of phosphoric acid due to evaporation and/or the loss of water when the temperature was raised. In contrast, the 
TABle 3: Membrane and cathode resistances in $5 \mathrm{wt} \% \mathrm{PBI}$ electrodes.

\begin{tabular}{lcc}
\hline $\begin{array}{l}\text { Temperature } \\
\left({ }^{\circ} \mathrm{C}\right)\end{array}$ & $\begin{array}{c}\text { Membrane } \\
\text { resistance } \\
\left(\mathrm{Ohm}-\mathrm{cm}^{2}\right)\end{array}$ & $\begin{array}{c}\text { Cathode } \\
\text { resistance } \\
\left(\mathrm{Ohm}-\mathrm{cm}^{2}\right)\end{array}$ \\
\hline 140 & 0.12 & 0.08 \\
160 & 0.13 & 0.11 \\
180 & 0.14 & 0.21 \\
200 & 0.15 & 0.36 \\
\hline
\end{tabular}

membranes with high amounts of phosphoric acid exhibit large conductivities and are constant at all temperatures.

3.5. Mass Transfer Resistance in the Cathode. Using oxygen as an oxidant, impedance spectra are recorded at low-current densities to estimate mass transfer resistances through the ionomer layer which covers the catalyst active surface. Since the experiments were performed with oxygen, the diffusion resistance is not likely within the porous electrode structure, but rather through the polymer/PA surface film covering the catalyst particle. The effect of the concentration of PBI in the electrode on the mass transport resistance is shown in Figure 6. The observed arc is contributed to both charge transfer resistance $\left(\mathrm{R}_{\mathrm{ct}}\right)$ and mass transfer resistance (generalized finite Warburg element, short circuit terminus); the model employed is schematically drown in Figure 4(b). When the PBI content is increased from 1 to $5 \mathrm{wt} . \%$, there is a slight decrease in the diameter of the impedance arc. This can be explained as a consequence of more penetration of phosphoric acid in the case of $1 \mathrm{wt} \%$ electrodes. When the $\mathrm{PBI}$ content is raised from 5 to $30 \mathrm{wt} . \%$, there is an increase in arc diameter, which implies more mass transfer resistances. The high mass transfer resistance in the electrodes with PBI content beyond $5 \mathrm{wt} . \%$ is due to the excessive penetration of PBI and phosphoric acid, which decreases electrode porosity and obstructs access to the surface of catalyst.

Quantitatively, mass transfer resistance (Warburg impedance) was determined by fitting the experimental data with Randles equivalent circuit (model that describes the mass transport in series with the electrochemical reaction at the electrode active surface: $R_{h f}\left[\mathrm{CPE}\left(R_{c t} \mathrm{~W}\right)\right]$. The value of charge transfer resistance $\left(R_{c t}\right)$ was calculated from the theoretical Tafel slope by using:

$$
R_{c t}=\frac{\text { Tafel slope }}{2.303 i},
$$

where $i$ is the current density. Theoretical Tafel slope can be obtained using:

$$
\text { Theor.Tafel slope }=\frac{2.303 R T}{\alpha n \mathrm{~F}},
$$

where $R$ is the gas constant, $T$ is the absolute temperature, $\alpha$ is the symmetry factor (in the case of $\mathrm{O}_{2}$ reduction $\alpha=0.5$ ), $n$ is number of electrons involved in the reaction and $\mathrm{F}$ is the Faraday constant.

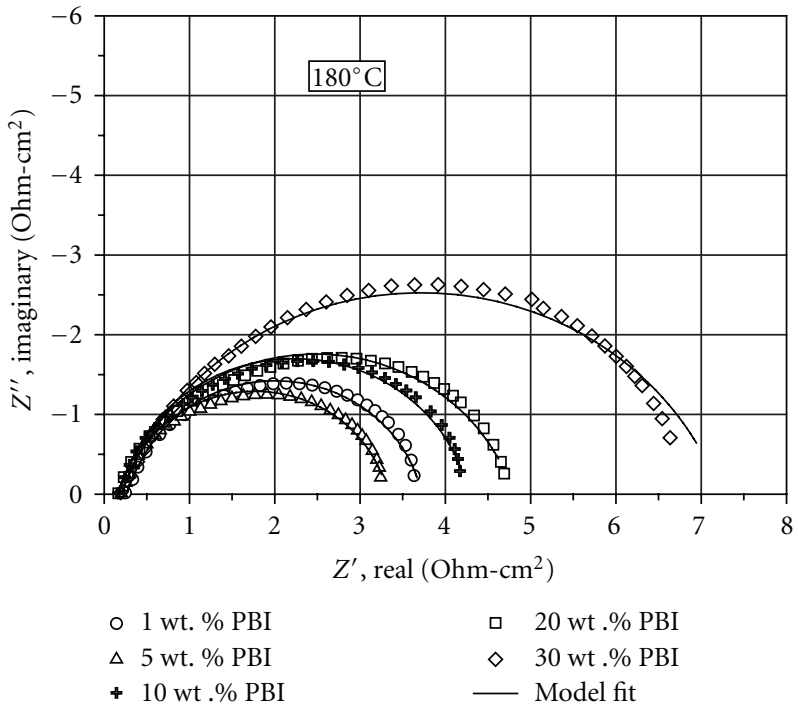

FIgure 6: Nyquist plot showing the effect of electrode PBI content on cathode mass transfer resistance at $180^{\circ} \mathrm{C}$. Current: $0.1 \mathrm{~A} ; \mathrm{H}_{2}$ stoichiometric ratio: $1.2 ; \mathrm{O}_{2}$ stoichiometric ratio: 2 ; minimum flow: $0.2 \mathrm{~L} \mathrm{~min}^{-1}$; pressure: $1 \mathrm{~atm}$; platinum loading (anode and cathode): $0.4 \mathrm{mg} \mathrm{cm}^{-2}$.

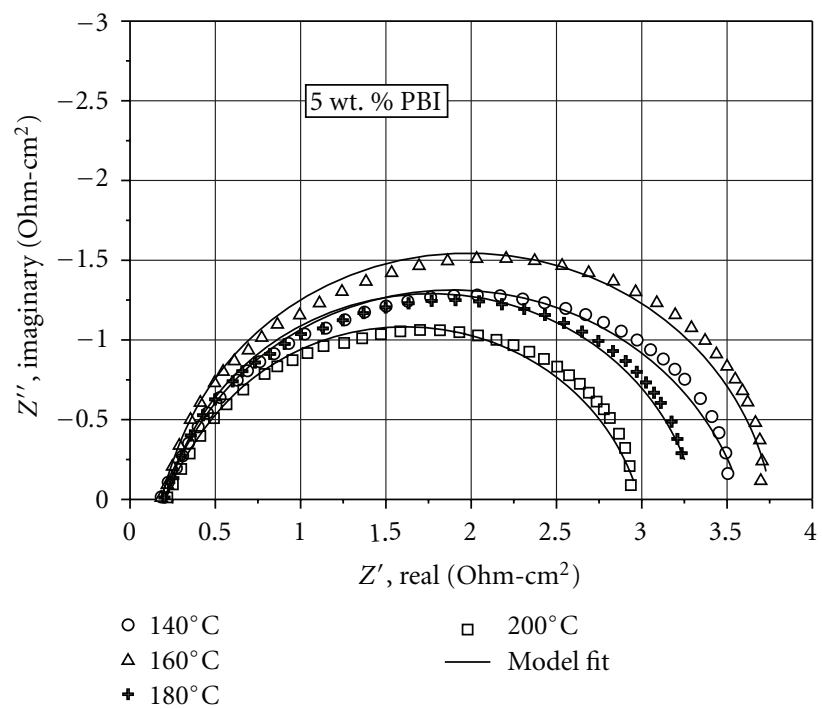

Figure 7: Nyquist plot showing the effect of temperature on cathode mass transfer resistance in $5 \mathrm{wt} . \% \mathrm{PBI}$ electrodes. Current: $0.1 \mathrm{~A} . \mathrm{H}_{2}$ stoichiometric ratio: $1.2 ; \mathrm{O}_{2}$ stoichiometric ratio: 2; minimum flow: $0.2 \mathrm{~L} \mathrm{~min}^{-1}$; pressure: $1 \mathrm{~atm}$; platinum loading (anode and cathode): $0.4 \mathrm{mg} \mathrm{cm}^{-2}$.

The parameters of Warburg element obtained by fitting experimental data at $180^{\circ} \mathrm{C}$ is given in Table 4 . Warburg resistances are higher than in Nafion-based MEAs as consequence of low catalyst loading, strong adsorption of phosphate, high coverage of catalyst surface by PBI as well as low solubility of oxygen in the polymer [31]. The Warburg resistance increases 2.5-fold when the PBI increases from 5 to $30 \mathrm{wt} \%$, reaching values as high as $6.25 \mathrm{Ohm}-\mathrm{cm}^{2}$. Time constant 
TABle 4: Warburg impedance for PBI-based MEAs at $180^{\circ} \mathrm{C}$.

\begin{tabular}{lcc}
\hline PBI content (wt.\%) & $\begin{array}{c}\text { Warburg impedance } \\
(\mathrm{R}, \text { Ohm-cm })^{2}\end{array}$ & $S=L^{2} / D(\mathrm{~s})$ \\
\hline 1 & 2.19 & 0.023 \\
5 & 1.84 & 0.017 \\
10 & 2.83 & 0.030 \\
20 & 3.85 & $3 \mathrm{E}-04$ \\
30 & 6.25 & $3 \mathrm{E}-07$ \\
\hline
\end{tabular}

$\mathrm{S}$ is a time constant; $\mathrm{L}$ is the effective diffusion thickness, and $\mathrm{D}$ the effective diffusion coefficient.

TABLE 5: Warburg impedance in 5 wt.\% PBI-based MEAs.

\begin{tabular}{lcc}
\hline Temperature $\left({ }^{\circ} \mathrm{C}\right)$ & $\begin{array}{c}\text { Warburg impedance } \\
\left(\mathrm{R}, \text { Ohm- } \mathrm{cm}^{2}\right)\end{array}$ & $S=L^{2} / D(\mathrm{~s})$ \\
\hline 140 & 2.26 & 0.023 \\
160 & 2.37 & 0.019 \\
180 & 1.84 & 0.017 \\
200 & 1.45 & 0.020 \\
\hline
\end{tabular}

of Warburg element is in the range $10-30 \mathrm{~ms}$ at low PBI loadings and tends to zero for higher loadings.

Temperature also has a strong effect on mass transport resistances in the electrodes. When the temperature is raised from $140^{\circ} \mathrm{C}$ to $200^{\circ} \mathrm{C}$, there is a decrease in mass transport resistances as illustrated by the decrease of arc diameters in Nyquist plots shown in Figure 7. The Warburg resistances that are calculated as explained above, decreased from 2.3 to $1.4 \mathrm{Ohm}-\mathrm{cm}^{2}$ when the temperature of the fuel cell was raised (Table 5). The decrease of mass transfer resistances can be explained by the increase of the diffusion coefficient with temperature.

\section{Conclusions}

The effect of the amount of PBI in the electrode on the overall performance was studied in this work. Analysis of polarization curves in the interval $140^{\circ} \mathrm{C}-200^{\circ} \mathrm{C}$, using MEAs with different electrode compositions, show that best performance was obtained with electrodes having $5 \mathrm{wt} . \%$ PBI. The optimum temperature of operation was $180^{\circ} \mathrm{C}$, and in these conditions, $200 \mathrm{~mA} \mathrm{~cm}^{-2}$ at a voltage of $0.58 \mathrm{~V}$ were produced using dry hydrogen and oxygen at atmospheric pressure. Membrane resistances of in house MEAs were in the interval $0.1-0.2 \mathrm{Ohm}-\mathrm{cm}^{2}$ depending on the experimental conditions.

The impedance spectra together with polarization data allow understanding transport losses in the PEMFCs at high temperatures $\left(140^{\circ} \mathrm{C}-200^{\circ} \mathrm{C}\right)$. The increase of PBI concentration in the electrodes from 1 to $10 \mathrm{wt} . \%$ decreases ionic resistance at $180^{\circ} \mathrm{C}$ from 0.29 to $0.14 \mathrm{Ohm}-\mathrm{cm}^{2}$, and further increase of PBI content has no effect. Cathode resistance also increases with the temperature of operation. In the case of $5 \mathrm{wt} \%$ electrodes, a 3 -fold increase in the cathode resistance was observed when the temperature was raised from 140 to $180^{\circ} \mathrm{C}$.
Impedance spectra recorded using oxygen as an oxidant in the region of activation loss was used to estimate masstransfer resistances through the ionomer layer, which covers the catalyst active surface. When the PBI content is raised from 1 to $5 \mathrm{wt} \%$, there is a slight decrease in Warburg impedance, but further increase in PBI concentration results in more mass transfer resistances that lead to an increase in arc diameter in Nyquist plot. At $180^{\circ} \mathrm{C}$, Warburg resistance increases 2.5-fold when the PBI increases from 5 to $30 \mathrm{wt}$ \%, reaching resistance values of $6 \mathrm{Ohm}-\mathrm{cm}^{2}$. Temperature also has a strong effect on mass transport within the electrodes. When the temperature is raised from $140^{\circ} \mathrm{C}$ to $200^{\circ} \mathrm{C}$, there is a decrease in Warburg resistance from 2.3 to $1.4 \mathrm{Ohm}-\mathrm{cm}^{2}$. The obtained results from impedance data were in accordance with the polarization curves, and optimum performance was obtained when overall resistance was minimal.

\section{Acknowledgments}

This work is supported by U.S-DOD-ARO under the Grant no. W911NF-08-C-0415. BRB and his scholars (Javier Parrondo, Ch. V. Rao and Mrs. S. Ghatty) thank Dr. Robert Mantz (Electrochemistry and Advanced Energy Conversion) at ARO-Chemical Sciences and Dr. Thomas L. Reitz (Electrochemistry and Thermal Sciences at AFRL, Wright Patterson Airbase, $\mathrm{OH}$ ) for supporting fuel cell research at SUBR.

\section{References}

[1] J. Zhang, Z. Xie, J. Zhang et al., "High temperature PEM fuel cells," Journal of Power Sources, vol. 160, no. 2, pp. 872-891, 2006.

[2] J. S. Wainright, J.-T. Wang, D. Weng, R. F. Savinell, and M. Litt, "Acid-doped polybenzimidazoles: a new polymer electrolyte," Journal of the Electrochemical Society, vol. 142, no. 7, pp. L121L123, 1995.

[3] J.-T. Wang, R. F. Savinell, J. Wainright, M. Litt, and H. Yu, "A $\mathrm{H}_{2} / \mathrm{O}_{2}$ fuel cell using acid doped polybenzimidazole as polymer electrolyte," Electrochimica Acta, vol. 41, no. 2, pp. 193-197, 1996.

[4] J. Kerres, A. Ullrich, F. Meier, and T. Häring, "Synthesis and characterization of novel acid-base polymer blends for application in membrane fuel cells," Solid State Ionics, vol. 125, no. 1, pp. 243-249, 1999.

[5] Q. Li, R. He, J.-A. Gao, J. O. Jensen, and N. J. Bjerrum, "The CO poisoning effect in PEMFCs operational at temperatures up to $200^{\circ}$ C," Journal of the Electrochemical Society, vol. 150, no. 12, pp. A1599-A1605, 2003.

[6] Y.-L. Ma, J. S. Wainright, M. H. Litt, and R. F. Savinell, "Conductivity of PBI membranes for high-temperature polymer electrolyte fuel cells," Journal of the Electrochemical Society, vol. 151, no. 1, pp. A8-A16, 2004.

[7] H. Pu, W. H. Meyer, and G. Wegner, "Proton transport in polybenzimidazole blended with $\mathrm{H}_{3} \mathrm{PO}_{4}$ or $\mathrm{H}_{2} \mathrm{SO}_{4}$," Journal of Polymer Science, Part B, vol. 40, no. 7, pp. 663-669, 2002.

[8] W. H. J. Hogarth, J. C. Diniz Da Costa, and G. Q. Lu, "Solid acid membranes for high temperature $\left(>140^{\circ} \mathrm{C}\right)$ proton exchange membrane fuel cells," Journal of Power Sources, vol. 142, no. 1-2, pp. 223-237, 2005. 
[9] Q. Li, H. A. Hjuler, and N. J. Bjerrum, "Phosphoric acid doped polybenzimidazole membranes: physiochemical characterization and fuel cell applications," Journal of Applied Electrochemistry, vol. 31, no. 7, pp. 773-779, 2001.

[10] O. E. Kongstein, T. Berning, B. Børresen, F. Seland, and R. Tunold, "Polymer electrolyte fuel cells based on phosphoric acid doped polybenzimidazole (PBI) membranes," Energy, vol. 32, no. 4, pp. 418-422, 2007.

[11] K.-L. Hsueh, E. R. Gonzalez, and S. Srinivasan, "Electrolyte effects on oxygen reduction kinetics at platinum: a rotating ring-disc electrode analysis," Electrochimica Acta, vol. 28, no. 5, pp. 691-697, 1983.

[12] J. Lobato, P. Cañizares, M. A. Rodrigo, J. J. Linares, and G. Manjavacas, "Synthesis and characterisation of poly[2,2(m-phenylene)-5,5-bibenzimidazole] as polymer electrolyte membrane for high temperature PEMFCs," Journal of Membrane Science, vol. 280, no. 1-2, pp. 351-362, 2006.

[13] J. Mader, L. Xiao, T. J. Schmidt, and B. C. Benicewicz, "Polybenzimidazole/acid complexes as high-temperature membranes," Advances in Polymer Science, vol. 216, no. 1, pp. 63124, 2008.

[14] R. He, Q. Li, A. Bach, J. O. Jensen, and N. J. Bjerrum, "Physicochemical properties of phosphoric acid doped polybenzimidazole membranes for fuel cells," Journal of Membrane Science, vol. 277, no. 1-2, pp. 38-45, 2006.

[15] J.-M. Bae, I. Honma, M. Murata, T. Yamamoto, M. Rikukawa, and N. Ogata, "Properties of selected sulfonated polymers as proton-conducting electrolytes for polymer electrolyte fuel cells," Solid State Ionics, vol. 147, no. 1-2, pp. 189-194, 2002.

[16] J. Jouanneau, R. Mercier, L. Gonon, and G. Gebel, "Synthesis of sulfonated polybenzimidazoles from functionalized monomers: preparation of ionic conducting membranes," Macromolecules, vol. 40, no. 4, pp. 983-990, 2007.

[17] L. Xiao, H. Zhang, E. Scanlon et al., "High-temperature polybenzimidazole fuel cell membranes via a sol-gel process," Chemistry of Materials, vol. 17, no. 21, pp. 5328-5333, 2005.

[18] L. Xiao, H. Zhang, T. Jana et al., "Synthesis and characterization of pyridine-based polybenzimidazoles for high temperature polymer electrolyte membrane fuel cell applicationsx," Fuel Cells, vol. 5, no. 2, pp. 287-295, 2005.

[19] S. Yu, L. Xiao, and B. C. Benicewicz, "Durability studies of PBI-based high temperature PEMFCs," Fuel Cells, vol. 8, no. 3-4, pp. 165-174, 2008.

[20] J.-H. Kim, H.-J. Kim, T.-H. Lim, and H.-I. Lee, "Dependence of the performance of a high-temperature polymer electrolyte fuel cell on phosphoric acid-doped polybenzimidazole ionomer content in cathode catalyst layer," Journal of Power Sources, vol. 170, no. 2, pp. 275-280, 2007.

[21] F. Seland, T. Berning, B. Børresen, and R. Tunold, "Improving the performance of high-temperature PEM fuel cells based on PBI electrolyte," Journal of Power Sources, vol. 160, no. 1, pp. 27-36, 2006.

[22] A. Pozio, M. De Francesco, A. Cemmi, F. Cardellini, and L. Giorgi, "Comparison of high surface $\mathrm{Pt} / \mathrm{C}$ catalysts by cyclic voltammetry," Journal of Power Sources, vol. 105, no. 1, pp. 1319, 2002.

[23] M. C. Lefebvre, R. B. Martin, and P. G. Pickup, "Characterization of ionic conductivity profiles within proton exchange membrane fuel cell gas diffusion electrodes by impedance spectroscopy," Electrochemical and Solid-State Letters, vol. 2, no. 6, pp. 259-261, 1999.

[24] Y. Liu, M. Murphy, D. R. Baker et al., "Determination of electrode sheet resistance in cathode catalyst layer by $\mathrm{AC}$ impedance," in Proton Exchange Membrane Fuel Cells 7, T. Fuller et al., Ed., vol. 11, p. 473, The Electrochemical Society Inc., Pennington, NJ, USA, 2007.

[25] T. J. Schmidt and J. Baurmeister, "Properties of hightemperature PEFC Celtec ${ }^{\circledR}$-P 1000 MEAs in start/stop operation mode," Journal of Power Sources, vol. 176, no. 2, pp. 428434, 2008.

[26] M. Geormezi, V. Deimede, N. Gourdoupi, N. Triantafyllopoulos, S. Neophytides, and J. K. Kallitsis, "Novel pyridine-based poly(ether sulfones) and their study in high temperature PEM fuel cells," Macromolecules, vol. 41, no. 23, pp. 9051-9056, 2008.

[27] J. Lobato, P. Cañizares, M. A. Rodrigo, J. J. Linares, and J. A. Aguilar, "Improved polybenzimidazole films for $\mathrm{H}_{3} \mathrm{PO}_{4}$ doped PBI-based high temperature PEMFC," Journal of Membrane Science, vol. 306, no. 1-2, pp. 47-55, 2007.

[28] P. Krishnan, J.-S. Park, and C.-S. Kim, "Performance of a poly(2,5-benzimidazole) membrane based high temperature PEM fuel cell in the presence of carbon monoxide," Journal of Power Sources, vol. 159, no. 2, pp. 817-823, 2006.

[29] E. W. Choe and A. B. Conciatori, US patent US4535144, 1985.

[30] K. A. Mauritz and R. B. Moore, "State of understanding of Nafion," Chemical Reviews, vol. 104, no. 10, pp. 4535-4585, 2004.

[31] L. Qingfeng, H. A. Hjuler, and N. J. Bjerrum, "Oxygen reduction on carbon supported platinum catalysts in high temperature polymer electrolytes," Electrochimica Acta, vol. 45 , no. 25-26, pp. 4219-4226, 2000. 


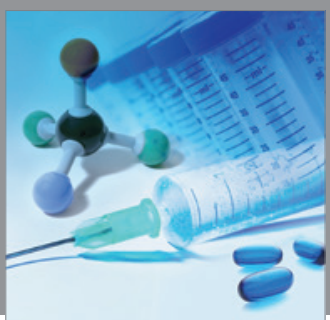

International Journal of

Medicinal Chemistry

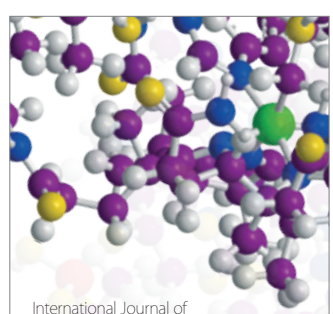

Carbohydrate Chemistry

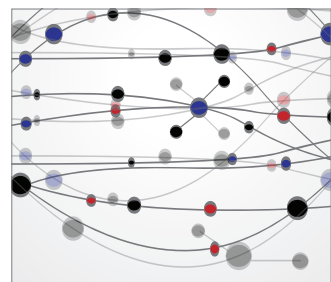

The Scientific World Journal
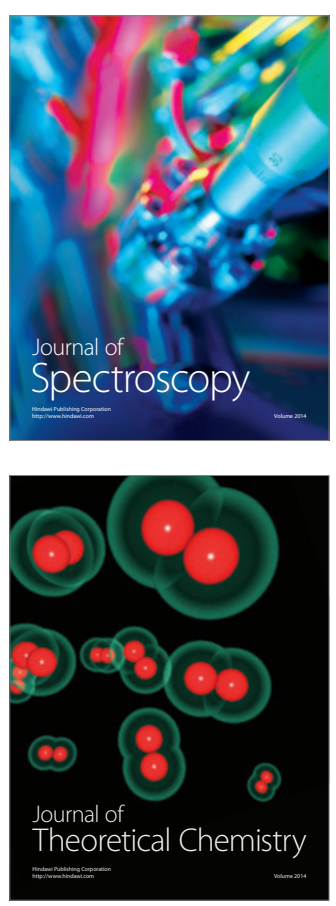
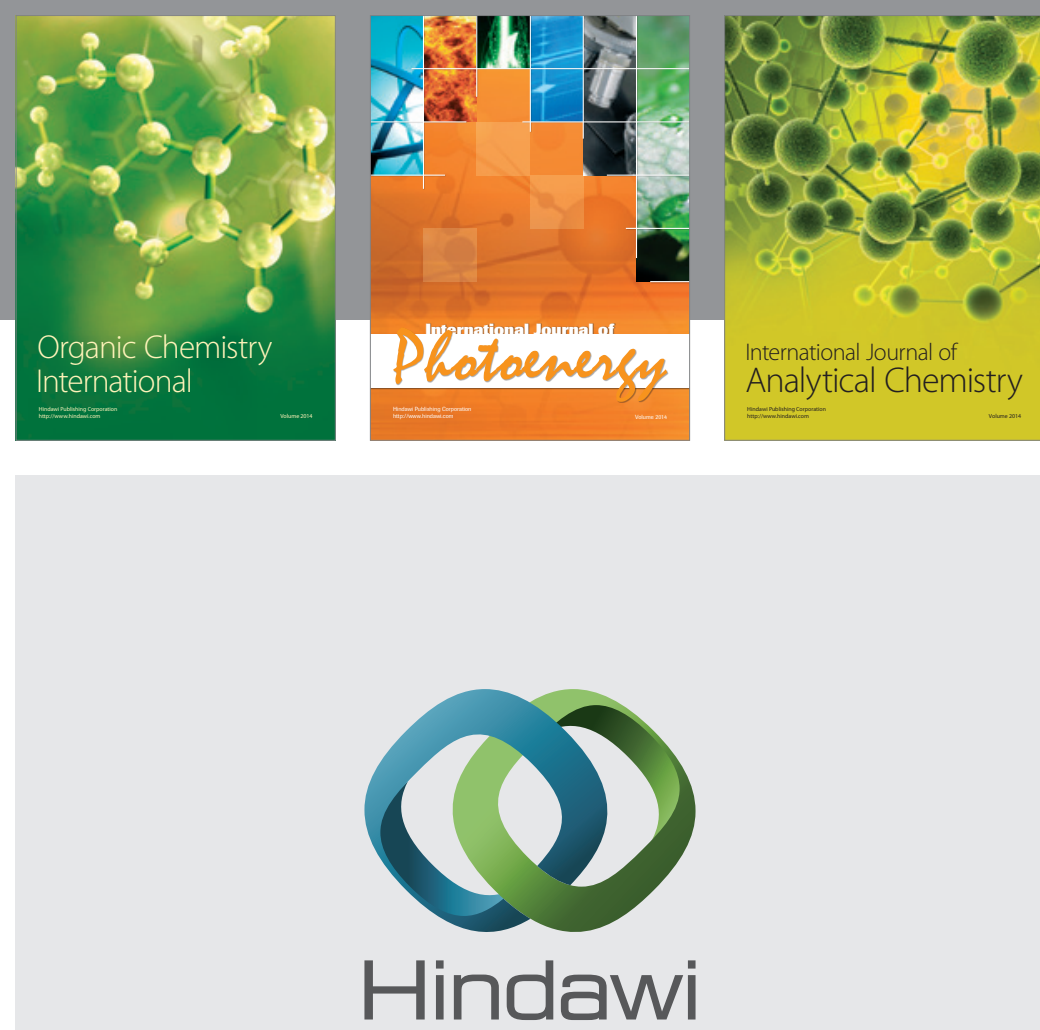

Submit your manuscripts at

http://www.hindawi.com
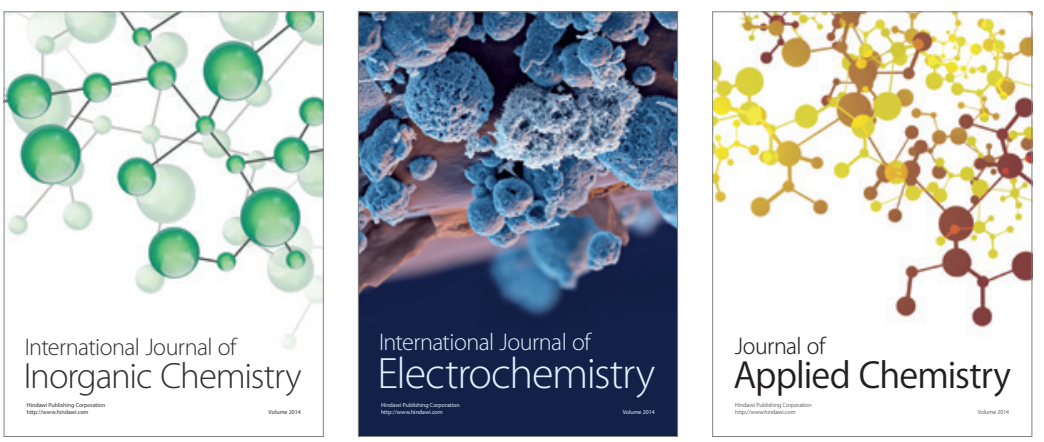

Journal of

Applied Chemistry
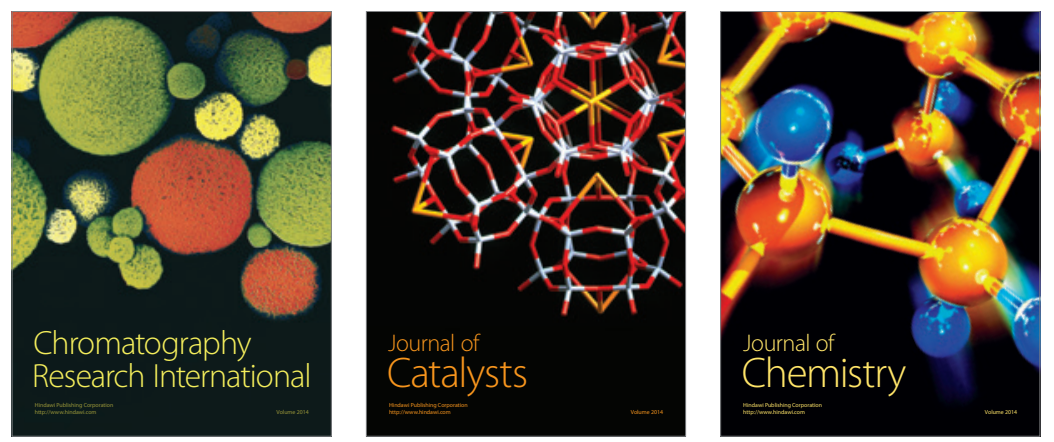
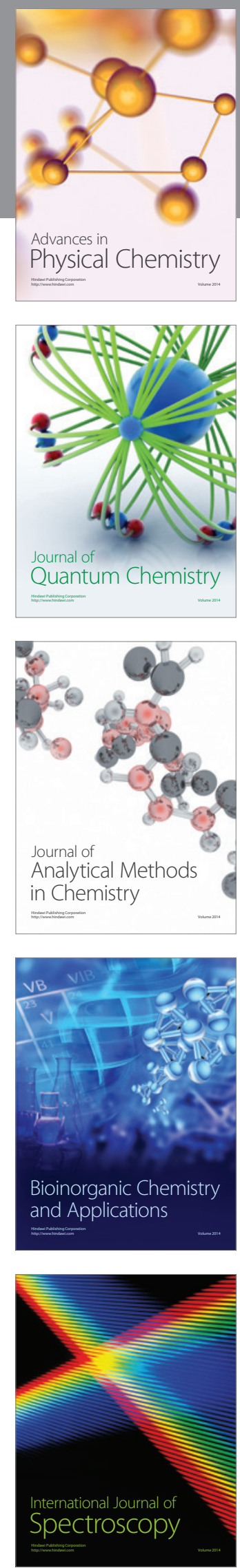